Available online on 15.03.2020 at http://jddtonline.info
Open Access to Pharmaceutical and Medical Research
unrestricted non-commercial use, provided the original work is properly cited

Open@ Access

Research Article

\title{
GC-MS Analysis of Bioactive Compounds and Phytochemical Evaluation of the Ethanolic Extract of Gomphrena globosa L. Flowers
}

\author{
Azmat Unnisa Esmat*, Sirisha Mittapally and Safiya Begum \\ Department of pharmaceutics, Deccan School of Pharmacy, Dar-us-salam, Aghapura, Hyderabad, telangana-500001
}

\begin{abstract}
Gomphrena globosa (L.) has high medicinal values. All parts are been used as folk medicines. The extract of whole plant / flowers has shown different phytochemical constituents with various clinical properties. These phytochemicals recognised are responsible for various activities such as anti-inflammatory, anticancer, antibacterial, analgesic and cytotoxic. The ethanolic extract of Gomphrena globosa L. flowers of biochemical test indicates the presence of sterols, triterpenoid, tannins, phenols and flavonoids, and on GC-MS analysis it has shown 11 phytochemical compounds with different pharmacological activities. The major bioactive compounds are Docosanoic Acid, Docosyl Ester (25.404\%) and Hexatriacontane (24.324\%), has proven anti-inflammatory activity.
\end{abstract}

Keywords: Gomphrena globose L., phytochemical constituents, GC-MS and anti-inflammatory.

Article Info: Received 11 Jan 2020; Review Completed 10 Feb 2020; Accepted 18 Feb 2020; Available online 15 March 2020

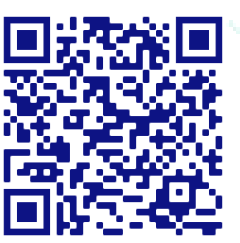

Cite this article as:

Esmat AU, Mittapally S, Begum S, GC-MS Analysis of Bioactive Compounds and Phytochemical Evaluation of the Ethanolic Extract of Gomphrena globosa L. Flowers, Journal of Drug Delivery and Therapeutics. 2020; 10(2):53-58 http://dx.doi.org/10.22270/jddt.v10i2.3914

Azmat Unnisa Esmat, Department of pharmaceutics, Deccan School of Pharmacy, Dar-us-salam, Aghapura, Hyderabad, telangana-500001

\section{INTRODUCTION:}

Natural products from plants are a rich resource used for centuries to cure various ailments. The use of bioactive plant-derived compounds is on the rise, because side effects of synthetic drugs can be even more dangerous than the diseases they claim to cure. In contrast, plant derived medicines contain natural substances that can promote health, alleviate illness and proved to be safe, better patient tolerance, relatively less expensive and globally competitive. So, in respect of the healing power of plants and a return to natural remedies is an absolute requirement of present and future time.[1,2,3]

Medicinal plants are a major natural alternative to synthetic drugs and gaining a lot of attention. The potential therapeutic activities are attributed to the presence of phytochemical constituents. Phytochemicals are present in the medicinal plants, leaves, flowers, vegetables and roots. Phytochemicals can be primary and secondary compounds. Chlorophyll, proteins and common sugars are included in primary constituents and secondary compounds have terpenoid, alkaloids and phenolic compounds. Terpenoids exhibit various important pharmacological activities i.e., antiinflammatory, anticancer, anti-malarial, inhibition of cholesterol synthesis, anti-viral and anti-bacterial activities.
Alkaloids are used as anaesthetic agents and are found in medicinal plants.[4-7]

For identification, qualitative and quantitative estimation of phytochemicals, different highly accurate procedures like GC-MS and HPTLC are commonly used to obtain the chemical fingerprint of high quality.

On interpretation of the fingerprint, it would be easier to elucidate the pharmacological activities of the phytochemicals. ${ }^{[8]}$

\section{MATERIALS AND METHODS}

\section{Collection and identification:}

The flowers of Gomphrena globosa L. of Indian origin were collected and spread on a plain paper and dried under shade at room temperature $\left(22^{\circ}-36^{\circ} \mathrm{C}\right)$ for about 10 days. The dried flowers are then used for further studies.

\section{Soxhlet extraction with ethanol:}

About 15gm of Gomphrena globosa L. dried flowers was uniformly packed into a thimble of soxhlet apparatus and extracted with $150 \mathrm{ml}$ of ethanol solvent and temperature was maintained at $50^{\circ} \mathrm{C}$.The process of extraction continued till the solvent insiphon tube of an extractor become colorless (approximately $4 \mathrm{hr}$ ). First cycle has taken 
$30 \mathrm{~min}$ and subsequently 17 cycles were done, where each cycle took approximately $8 \mathrm{~min}$. After that the extract was dried and solvent was recollected using rota vaporator. Dried powder transfer into sterilized bottle and stored at $8^{\circ} \mathrm{C}$ for further analysis.

\section{Qualitative biochemical analysis:}

The qualitative tests for various phytoconstituents as shown in table 1 was carried out by using ethanolic extract of Gomphrena globosa L. flowers. [9-14]

\section{Gas-Chromatography-Mass Spectrometry}

The GC-MS analysis of ethanolic extract of Gomphrena globosa L. flowers gives a fingerprint for the identification and quantification of phytochemical present. The GC-MS was performed at "“VIT-SIF Lab, SAS, Chemistry Division for NMR and GC-MS Analysis" India using a GC-MS Model; clarus 680 equipped with a fused silica column, packed with Elite-5MS (5\% biphenyl $95 \%$ dimethylpolysiloxane, $30 \mathrm{~m} \times 0.25 \mathrm{~mm}$ ID $\times 250 \mu \mathrm{m} \mathrm{df}$ ) and the components were separated using Helium as carrier gas at a constant flow of $1 \mathrm{ml} / \mathrm{min}$. The injector temperature was set at $260^{\circ} \mathrm{C}$ during the chromatographic run. The $1 \mu \mathrm{L}$ of extract sample injected into the instrument the oven temperature was as follows: $60^{\circ} \mathrm{C}(2 \mathrm{~min})$; followed by $300^{\circ} \mathrm{C}$ at the rate of $10^{\circ} \mathrm{C} \mathrm{min}-1$. and $300^{\circ} \mathrm{C}$, where it was held for $6 \mathrm{~min}$.

The mass detector conditions were maintained as: transfer line temperature $240{ }^{\circ} \mathrm{C}$; ion source temperature $240{ }^{\circ} \mathrm{C}$; and ionization mode electron impact at $70 \mathrm{eV}$, a scan time $0.2 \mathrm{sec}$ and scan interval of $0.1 \mathrm{sec}$. Fragments from 40 to $600 \mathrm{Da}$. The spectrums of the components were compared with the database of spectrum of known components stored in the GC-MS NIST (2008) library.

\section{RESULTS AND DISCUSSION:}

\section{Qualitative biochemical analysis:}

The qualitative tests for various phytoconstituents were carried out by using ethanolic extract of Gomphrena globosa L. flowers and the phytoconstituents present in it are shown in table 2.

\section{Chromatographical Analysis:}

Chromatographic fingerprint analysis of Indian variety dried flowers of ethanolic extract of Gomphrena globosa L. using GC-MS has shown 11 peaks indicating the presence of 11 phytochemical compounds.

The identification of the phytochemical compounds was based on the peak area, retention time and molecular formula as shown in table 3 .

The phytochemical compounds recognized through GC-MS analysis showed many biological activities are listed in Table 4

Individual phytochemical constituents in the ethanolic extract of Gomphrena globosa was given in table 5 as analysed by GC-MS analytical procedure.

Table 1: Qualitative biochemical analysis of ethanolic extract of Gomphrena globosa L. flowers

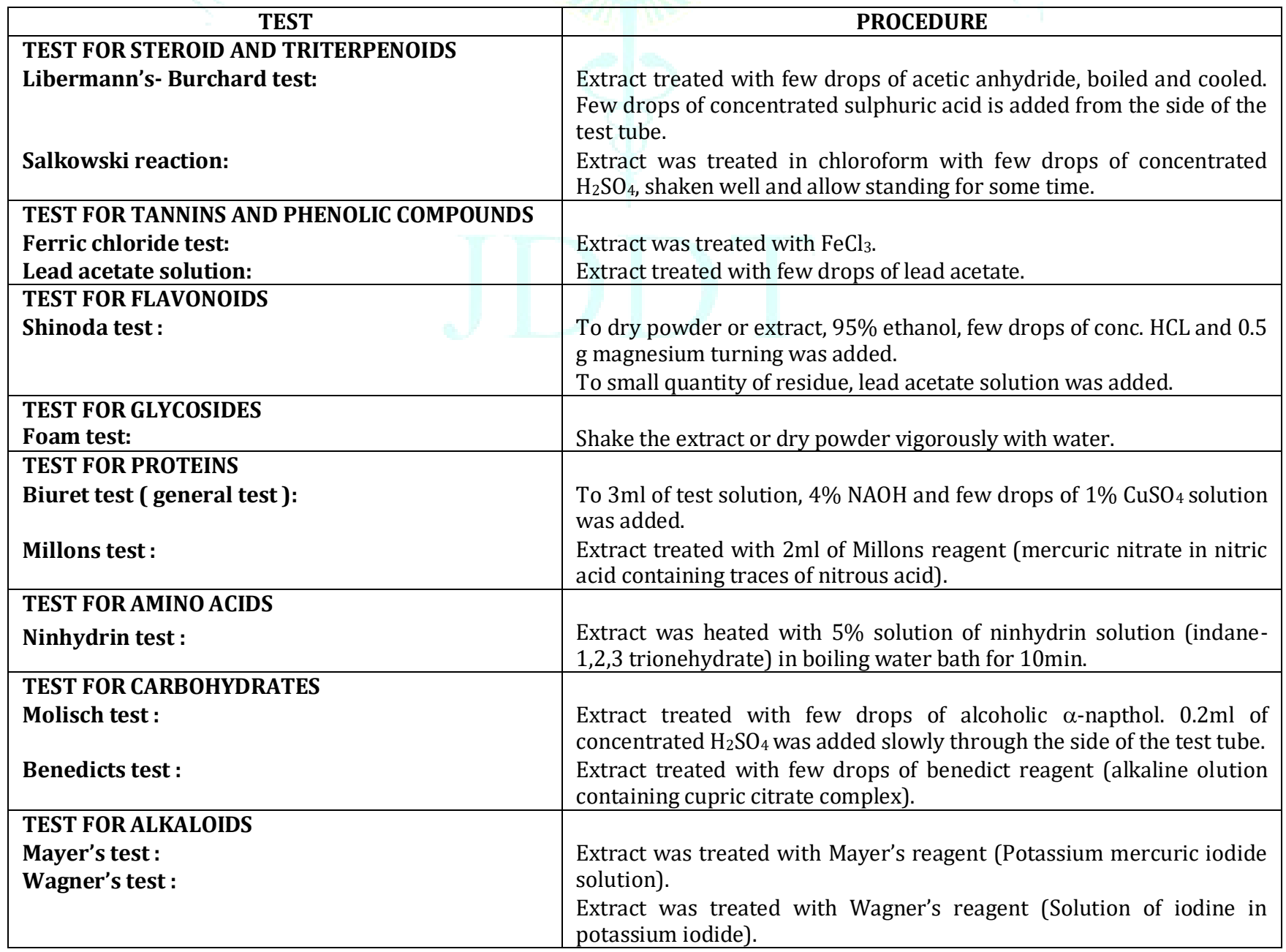


Table 2: Qualitative biochemical analysis of ethanolic extract of Gomphrena globosa L. flowers

\begin{tabular}{|c|c|c|}
\hline TEST & OBSERVATION & RESULT \\
\hline $\begin{array}{l}\text { TEST FOR STEROID AND TRITERPENOIDS } \\
\text { Libermann's- Burchard test: } \\
\text { Salkowski reaction: }\end{array}$ & $\begin{array}{l}\text { Brown ring at the junction of two layers and the } \\
\text { upper layer turns green which shows the presence } \\
\text { of sterols and formation of deep red colour } \\
\text { indicates the presence of triterpenoids. } \\
\text { - Red colour appears in the lower layer indicates the } \\
\text { presence of sterols and formation of yellow } \\
\text { coloured lower layer indicates the presence of } \\
\text { triterpenoids. }\end{array}$ & $\begin{array}{l}\text { Presence of } \\
\text { Steroid and } \\
\text { triterpenoids }\end{array}$ \\
\hline $\begin{array}{l}\text { TEST FOR TANNINS AND PHENOLIC } \\
\text { COMPOUNDS } \\
\text { Ferric chloride test: } \\
\text { Lead acetate solution: }\end{array}$ & $\begin{array}{l}\text { - } \quad \text { Blue-black colour. } \\
\text { - White precipitate. }\end{array}$ & $\begin{array}{l}\text { Presence of } \\
\text { tannins and } \\
\text { phenolic } \\
\text { compounds }\end{array}$ \\
\hline $\begin{array}{l}\text { TEST FOR FLAVONOIDS } \\
\text { Shinoda test : }\end{array}$ & $\begin{array}{l}\text { - } \quad \text { Orange, pink, red to purple colour appears. } \\
\text { - } \quad \text { Yellow coloured precipitate is formed. }\end{array}$ & $\begin{array}{l}\text { Presence of } \\
\text { flavonoids. }\end{array}$ \\
\hline $\begin{array}{l}\text { TEST FOR GLYCOSIDES } \\
\text { Foam test: }\end{array}$ & $\begin{array}{l}\text { - } \quad \text { Absence of persistent foam. } \\
\text { - } \quad \text { Absence of blue or green fluroscence. }\end{array}$ & $\begin{array}{l}\text { Absence of } \\
\text { glycosides. }\end{array}$ \\
\hline $\begin{array}{l}\text { TEST FOR PROTEINS } \\
\text { Biuret test ( general test ): } \\
\text { Millons test : }\end{array}$ & $\begin{array}{l}\text { - Absence of violet or pink colour. } \\
\text { - } \quad \text { Absence of white precipitate. }\end{array}$ & $\begin{array}{l}\text { Absence of } \\
\text { proteins. }\end{array}$ \\
\hline $\begin{array}{l}\text { TEST FOR AMINO ACIDS } \\
\text { Ninhydrin test : }\end{array}$ & - Absence of purple or bluish colour. & $\begin{array}{l}\text { Absence of } \\
\text { amino acids }\end{array}$ \\
\hline $\begin{array}{l}\text { TEST FOR CARBOHYDRATES } \\
\text { Molisch test : } \\
\text { Benedicts test : }\end{array}$ & $\begin{array}{l}\text { - Absence of purple to violet colour at the junction. } \\
\text { - Upon boiling on water bath reddish brown } \\
\text { precipitate doesn't forms, therefore reducing } \\
\text { sugars are absent. }\end{array}$ & $\begin{array}{l}\text { Absence of } \\
\text { carbohydrate. }\end{array}$ \\
\hline $\begin{array}{l}\text { TEST FOR ALKALOIDS } \\
\text { Mayer's test : } \\
\text { Wagner's test : }\end{array}$ & $\begin{array}{l}\text { Absence of cream colour precipitate. } \\
\text { - } \quad \text { Absence of reddish brown precipitate. }\end{array}$ & $\begin{array}{l}\text { Absence of } \\
\text { alkaloids. }\end{array}$ \\
\hline
\end{tabular}

Table 3: GC MS analysis of ethanolic extract of Gomphrena globosa L. flowers.

\begin{tabular}{|c|c|c|c|c|c|c|}
\hline $\begin{array}{l}\text { S. } \\
\text { no }\end{array}$ & Peak name & $\begin{array}{l}\text { Molecular } \\
\text { formula }\end{array}$ & $\begin{array}{l}\text { Molecular } \\
\text { weight }\end{array}$ & $\begin{array}{l}\text { Retention } \\
\text { time }\end{array}$ & Area & \% Area \\
\hline 1 & SULFUROUS ACID, OCTADECYL 2-PROPYL ESTER & $\mathrm{C}_{21} \mathrm{H}_{44} \mathrm{O}_{3} \mathrm{~S}$ & 376 & 25.353 & $325,175.2$ & 1.306 \\
\hline 2 & $\begin{array}{l}\text { 1,6;3,4-DIANHYDRO-2-DEOXY-.BETA.-D-RIBO- } \\
\text { HEXOPYRANOSE }\end{array}$ & $\mathrm{C}_{6} \mathrm{H}_{8} \mathrm{O}_{3}$ & 128 & 25.553 & $382,412.1$ & 1.536 \\
\hline 3 & 17-PENTATRIACONTENE & $\mathrm{C}_{35} \mathrm{H}_{70}$ & 490 & 26.093 & $4,471,202.5$ & 17.961 \\
\hline 4 & DOCOSANOIC ACID, DOCOSYL ESTER & $\mathrm{C}_{44} \mathrm{H}_{88} \mathrm{O}_{2}$ & 648 & 26.583 & $6,323,849.0$ & 25.404 \\
\hline 5 & HEXATRIACONTANE & $\mathrm{C}_{36} \mathrm{H}_{74}$ & 506 & 26.763 & $6,055,150.5$ & 24.324 \\
\hline 6 & 17-PENTATRIACONTENE & $\mathrm{C}_{35} \mathrm{H}_{70}$ & 490 & 27.324 & $1,216,819.6$ & 4.888 \\
\hline 7 & $\begin{array}{l}\text { CYCLOHEXANE, 1-(1,5-DIMETHYLHEXYL)-4-(4- } \\
\text { METHYLPENTYL)- }\end{array}$ & $\mathrm{C}_{20} \mathrm{H}_{40}$ & 280 & 27.364 & $1,078,786.8$ & 4.334 \\
\hline 8 & 17-PENTATRIACONTENE & $\mathrm{C}_{35} \mathrm{H}_{70}$ & 490 & 27.499 & $2,166,417.0$ & 8.703 \\
\hline 9 & 11-TRICOSENE & $\mathrm{C}_{23} \mathrm{H}_{46}$ & 322 & 28.069 & $1,918,735.1$ & 7.708 \\
\hline 10 & 1-PENTACONTANOL & $\mathrm{C}_{35} \mathrm{H}_{70}$ & 490 & 28.159 & $596,499.4$ & 2.396 \\
\hline 11. & $\begin{array}{l}\text { CYCLOHEXANE, 1-(1,5-DIMETHYLHEXYL)-4-(4- } \\
\text { METHYLPENTYL)- }\end{array}$ & $\mathrm{C}_{20} \mathrm{H}_{40}$ & 280 & 29.644 & $358,503.8$ & 1.440 \\
\hline
\end{tabular}


Table 4: Nature and the biological activities of phytoconstituents of ethonolic extract of Gomphrena globosa L. flowers.

\begin{tabular}{|c|c|c|c|c|}
\hline S.no & $\begin{array}{l}\text { Retention } \\
\text { time }\end{array}$ & $\begin{array}{l}\text { Peak area } \\
\%\end{array}$ & Name of the compound & Activity \\
\hline 1 & 25.353 & 1.306 & $\begin{array}{l}\text { Sulfurous Acid, Octadecyl 2- } \\
\text { Propyl Ester }\end{array}$ & Antibacterial activity[15] \\
\hline 2 & 25.553 & 1.536 & $\begin{array}{l}\text { 1,6;3,4-Dianhydro-2-Deoxy- } \\
\text {.Beta--D-Ribo-Hexopyranose }\end{array}$ & - \\
\hline 3 & 26.093 & 17.961 & 17-Pentatriacontene & $\begin{array}{l}\text { Anti-inflammatory, Anti cancer, Anti bacterial, Anti } \\
\text { arthritic and Anti microbial activity[16,17] }\end{array}$ \\
\hline 4 & 26.583 & 25.404 & Docosanoic Acid, Docosyl Ester & Emollient and skin conditioning[18,19] \\
\hline 5 & 26.763 & 24.324 & Hexatriacontane & $\begin{array}{l}\text { Anti inflammatory, analgesic activity, Radical } \\
\text { scavenger and Antioxidant activity[20-26] }\end{array}$ \\
\hline 6 & 27.324 & 4.888 & 17-Pentatriacontene & $\begin{array}{l}\text { Anti inflammatory, Anti cancer, Anti bacterial and } \\
\text { Anti arthritic and Anti microbial activity }{ }^{[16,17]}\end{array}$ \\
\hline 7 & 27.364 & 4.334 & $\begin{array}{l}\text { Cyclohexane, 1-(1,5- } \\
\text { Dimethylhexyl)-4-(4- } \\
\text { Methylpentyl)- }\end{array}$ & Anti bacterial and Anti cancer activity[27,28] \\
\hline 8 & 27.499 & 8.703 & 17-Pentatriacontene & $\begin{array}{l}\text { Anti inflammatory, Anti cancer ,Anti bacterial Anti } \\
\text { arthritic and Anti microbial activity[16,17] }\end{array}$ \\
\hline 9 & 28.069 & 7.708 & 11-Tricosene & - \\
\hline 10 & 28.159 & 2.396 & 1-Pentacontanol & - \\
\hline 11. & 29.644 & 1.440 & $\begin{array}{l}\text { Cyclohexane, 1-(1,5- } \\
\text { Dimethylhexyl)-4-(4- } \\
\text { Methylpentyl)- }\end{array}$ & Anti bacterial and Anti cancer activity ${ }^{[27,28]}$ \\
\hline
\end{tabular}

Table 5: The molecular structure, molecular formula and GC-MS spectrum of individual phytochemical components of the ethanolic extract of Gomphrena globosa L.flowers.

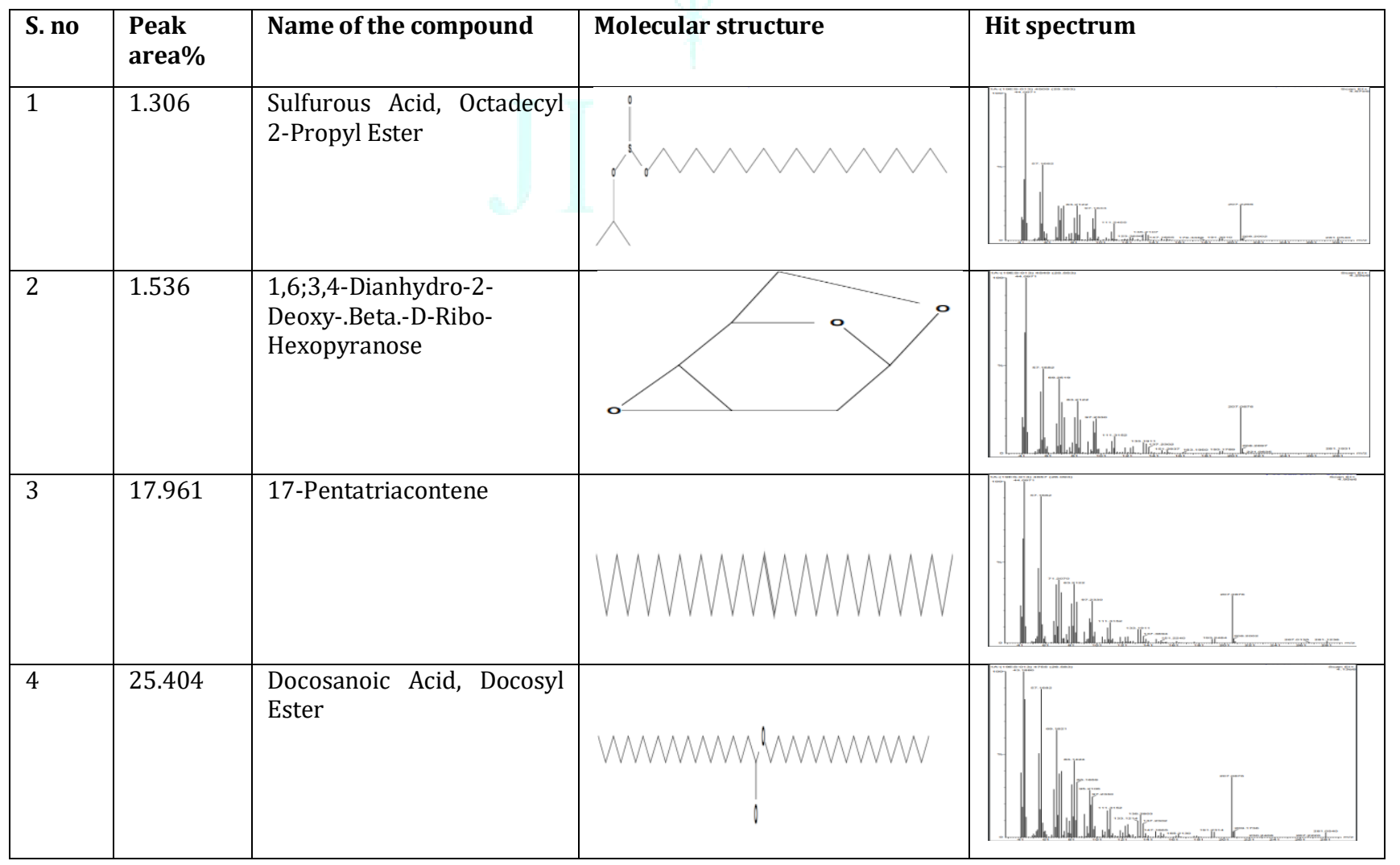




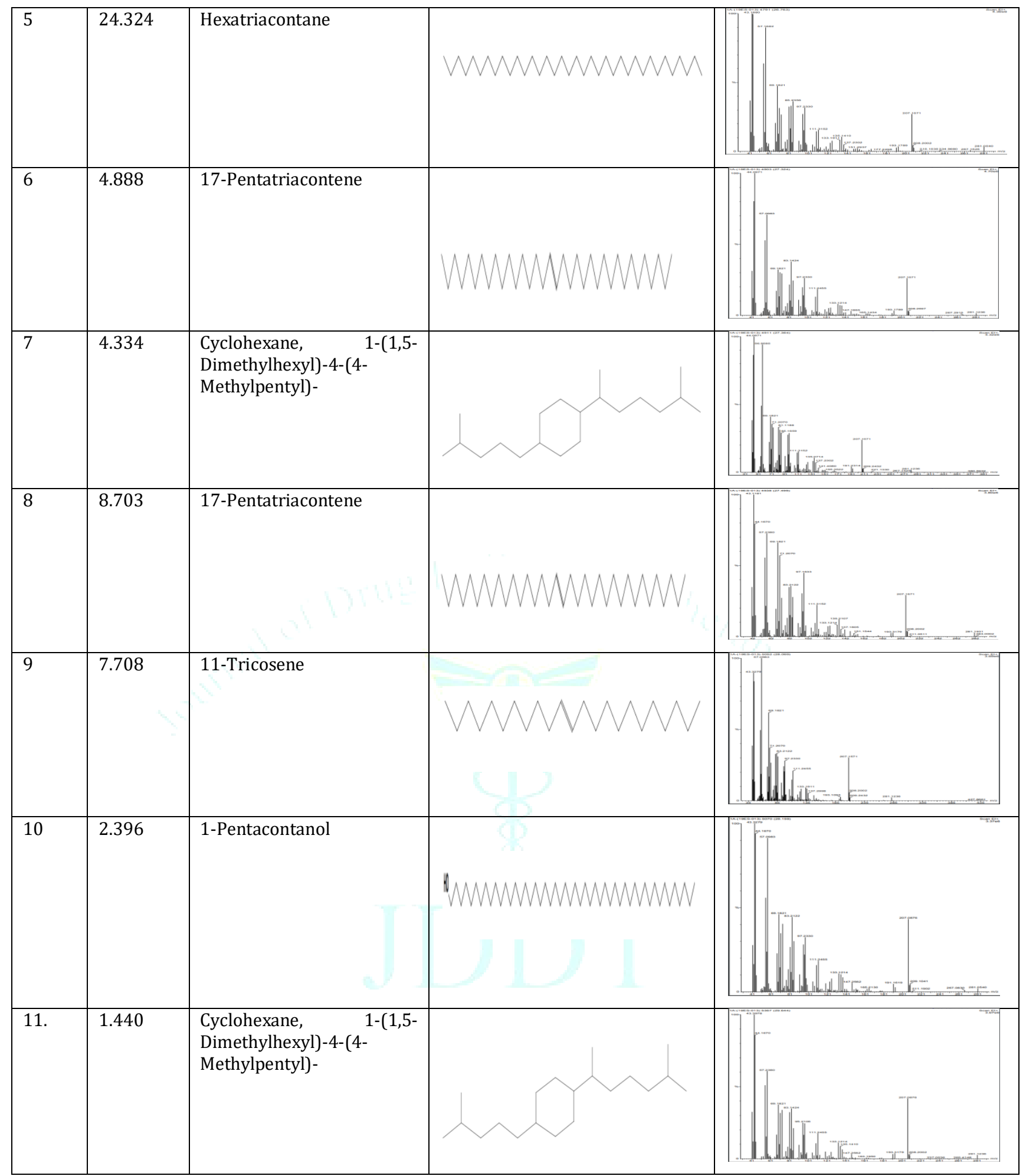

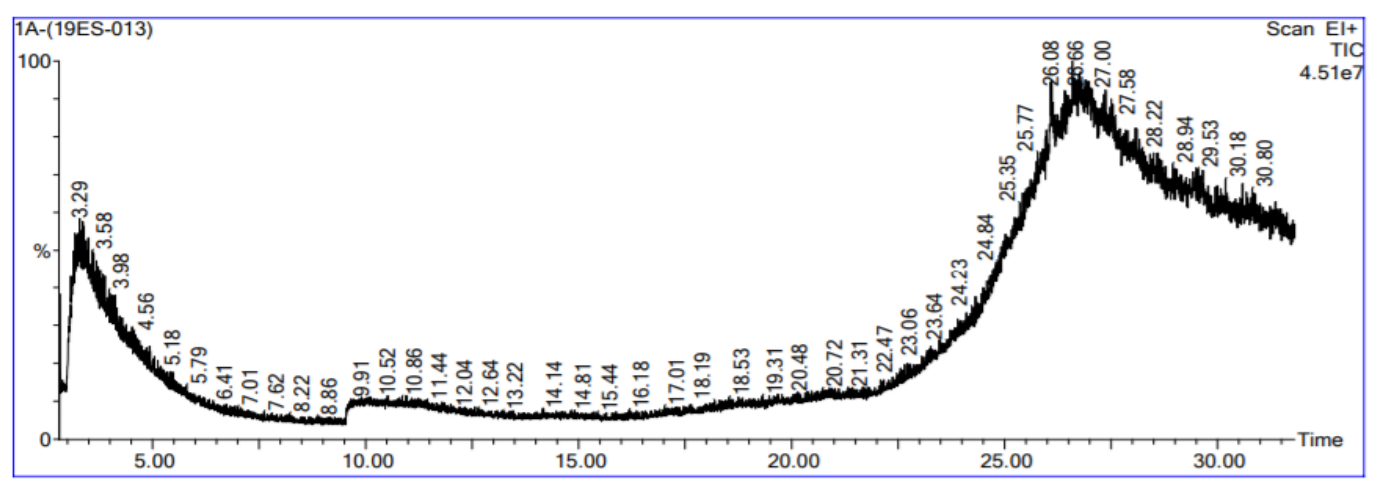

Figure 1: Chromatogram of ethanolic extract of Gomphrena globosa L. flowers. 


\section{CONCLUSION}

The plant Gomphrena globosa $L$. is highly valuable as traditional medicines in the treatment of various human ailments. Biochemical analysis of ethanolic extract of Gomphrena globosa L. has shown the presence of sterols, triterpenoid, tannins, phenols and flavonoids. On GC-MS analysis of ethanolic extract of Gomphrena globosa L. flowers of Indian origin has shown 11 prominent phytochemicals which are attributed with potential pharmacological activities such as antioxidant, anti-inflammatory, anticancer, anti arthritic and antibacterial. It was found that 7 phytochemicals have shown anti-inflammatory activity. Hence, it would be having a promising anti-inflammatory activity.

\section{REFERENCES}

1. Muhammad Ilyas et al., Biological Potential and Phytopharmacological Screening of Gomphrena Species, International Journal of Pharma Research \& Review, 2014; 3(1):58-66.

2. Ignacimuthu, S. and M. Ayyanar. Plants used for non-medicinal purposes by the tribal people in kalakad Mundanthurai Tiger reserve, Southern India. Indian Journal Traditional of Knowledge, 2009; 9(3):515-518.

3. Dias, D.A., R.M.X. De Moura, P.S. Pereira, A.H. Januàrio and S.C. França,. Antimicrobial screening and quantitative determination of benzoic acid derivative of Gomphrena celosioides by TLCDensitometry. Chem. Pharm. Bull. 2004; 52(11):1342-1344.

4. P Yamuna et al. Qualitative phytochemical analysis of Gomphrena globosa Linn. and Gomphrena decumbens Jacq., International Journal of Biology Research, 2017; 2(3):20-22.

5. Krishnaiah D, Sarbatly R, Bono A; Phytochemical antioxidants for health and medicine: A move towards nature. Biotechnol Mol Biol Rev, 2007; 1:97-104.

6. Mahato SB, Sen S. Advances in triterpenoid research, 19901994. Phytochemistry. 1997; 44:1185-1236.

7. Herouart D, Sangwan RS, Fliniaux MA, Sangwan-Norreel BS. Variations in the Leaf Alkaloid Content of Androgenic Diploid Plants of Datura innoxia. Planta Med.; 1988; 54:14-17.

8. P Yamuna et al., GC-MS analysis of bioactive compounds in the entire parts of ethanolic extract of Gomphrena globosa Linn., International Journal of Research in Pharmacy and Pharmaceutical Sciences, 2017; 2(4):57-64

9. Khandelwal KR. Chapter 25, Evaluation. In: Practical Pharmacognosy. 12th Edition. Pune: Nirali Prakashan, 2010; 25:1-25.8.

10. Harbone JB. 1973. Phytochemical methods. A guide to modern Techniques of plant Analysis. Chapman and Hall, London, 267270.

11. Khandelwal KR. Chapter 41, Evaluation. In: Practical Pharmacognosy. 19th Edition. Pune: Nirali Prakashan, 2008:157-158.

12. Raman N. Chapter 5, Qualitative Phytochemical Screening. In: Phytochemical Techniques. New Delhi: New India Publishing agency, 2006: 19-24.

13. P Yamuna et al., Qualitative Phytochemical Analysis of Gomphrena globosa Linn. and Gomphrena decumbens Jacq., International Journal of Biology Research, Volume 2017; 2(3):20-22.
14. Ayesha Siddiqua and Sirisha Mittapally, Formulation and Evaluation of ethanolic extract of Cissus quadrangularis herbal gel, International Research Journal of Pharmaceutical and Biosciences, 2017; 4(4): 9-29.

15. Babu et al., Phytochemical Analysis of Ficus arnottiana (Miq.) Miq. Leaf Extract Using GC-MS Analysis, International Journal of Pharmacognosy and Phytochemical Research; 2017; 9(6):775779.

16. Dinesh Kumar et al., GC-MS analysis of bioactive compounds from ethanolic leaves extract of Eichhornia crassipes (Mart) Solms. and their pharmacological activities, The Pharma Innovation Journal; 2018; 7(8):459-462.

17. Shubhangi Nagorao Ingole, Phytochemical Analysis of Ficus Religiosa L. (Moraceae) by GC-MS method, International Research Journal of Natural and Applied Sciences, 2017; 4(3):55-63.

18. Sunita Arora and Ganesh Kumar, Phytochemical screening of root, stem and leaves of Cenchrus biflorus Roxb, Journal of Pharmacognosy and Phytochemistry; 2018; 7(1):1445-1450.

19. Pratima Raypa et al., Analysis of Medicinally Important Phytocompounds from Adina cordifolia Leaves, International Journal of Current Microbiology and Applied Sciences; 2018; 7(11):3007-3019

20. Selvan et al., Bioactive compound identification, phytochemical estimation, In-Vitro Anti-Inflammatory and Antioxidant activity of Pupalia Lappacea, International Journal of Pharmacognosy; 2014; 1(9):596-604.

21. Pillai and Nair, GC-MS analysis of chloroform extract of Cleome Burmanni W. and A. (Cleomaceae), International Journal of Pharmaceutical Sciences and Research; 2013; 4(5):1930-1933.

22. Pandurangan A, Khosa RL and Hemalatha S, Anti-inflammatory and analgesic activity of Ichnocarpus frutescens. Pharmacologyonline; 2008; 1:392-399.

23. Sunita Arora and Sonam Meena, GC-MS Profiling of Ceropegia bulbosa Roxb. var.bulbosa, an endangered plant from Thar Desert, Rajasthan, The Pharma Innovation Journal; 2017; 6(11):568-573.

24. Shashikala A. et al., GC-MS analysis of phytocomponents in the methanolic extract of Propolis of Honey Bee, Asian Journal of Pharmaceutical Analysis and Medicinal Chemistry. 2016; 4(2):74-78.

25. Premjanu N, Jayanthy C. Antimicrobial activity of Diethyl Phthalate: An Insilico Approach, Asian Journal of Pharmaceutical and clinical Research, 2014; 7(4):141-142.

26. Ashwathanarayana $\mathrm{R}$ and Raja Naika. Anti-Inflammatory properties of Pavetta Crassicaulis Bremek. leaf and flower crude extracts and its pure compounds collected from Western Ghats, Karnataka, India, Asian Journal of Pharmaceutical and Clinical Research, 2018; 11(9):72-90.

27. Balasubramanian et al., GCMS And FTIR analysis on the methanolic extract of Coriandrum Sativum leaves, European Journal of Pharmaceutical and Medical Research, 2018; 5(8):454-460.

28. Aastha Bhardwaj, Najam A. Shakil, Vidyanath Jha, Rajinder Kumar Gupta. "Screening of nutritional, phytochemical, antioxidant and antibacterial activity of underutilized seeds of Scirpus articulatus: the basis of Khubahi Ramdana industry". Journal of pharmacognosy and phytochemistry; 2014; 3(4):1120. 